Marius CONKAN

Faculty of Letters, Babeș-Bolyai University

Cluj-Napoca, Romania mariusconkan@yahoo.com.sg

Daiana GÂRDAN

Faculty of Letters, Babeș-Bolyai University

Cluj-Napoca, Romania daiana.gardan@lett.ubbcluj.ro

\title{
SPACE IN LITERATURE AND LITERATURE IN SPACE INTRODUCTION
}

Recommended Citation: Conkan, Marius, Gârdan, Daiana. "Space in Literature and Literature in Space. Introduction”. Metacritic Journal for Comparative Studies and Theory 6.1 (2020): https://doi.org/10.24193/mjcst.2020.9.01

\begin{abstract}
The present introduction aims to outline the major theoretical approaches of spatial studies, together with their most relevant inquiries and pursuing their many methodological ramifications. Our main goal is to deliver a panoramic study engaging both traditional geocritical perspectives and contemporary transnational, quantitative, or digital studies that shaped the way in which we understand the notion of space and its literary functions. The present introduction targets national, transnational, and global projects, aiming to integrate Romanian debates in a broader, international dialogue. Our thematic issue gathers a diverse body of studies, each one of them advancing original approaches that employ comprehensive theoretical frameworks and different tools and perspectives, from symbolic geography and migrations studies to distant-reading and World Literature.
\end{abstract}

Keywords: qeocriticism, literary geography, spatial studies, transnational studies, World Literature. 
Geocriticism reveals the socio-cultural dynamics of the relationship between space in literature and literature in space, it "explores, seeks, surveys, digs into, reads, and writes a place; it looks at, listens to, touches, smells, and tastes spaces" (Tally Jr., Geocritical Explorations 3). These are the main issues addressed by Bertrand Westphal's geocritical endeavour, as he explores, in a geocentered, multifocal, and polysemantic manner, the "real-and-imagined spaces" (using Edward Soja's terms) which are not confined to literature alone. The spatial turn in the 1970 s can be seen as a "big bang" reasserting the importance of spatiality in socio-cultural studies, a path opened by Michel Foucault's "archaeologies" and "heterotopologies" and by Henri Lefebvre's Marxist critique of "the production of space". The origins of current spatial analyses can also be traced back to the chronotopic inquiries of Mikhail Bakhtin, in the poetics of space delivered by Gaston Bachelard, the poststructuralist geophilosophy of Gilles Deleuze and Félix Guattari, the postcolonial critique of Edward Said and Homi Bhabha, and in the feminist theories developed by Gloria Anzaldúa and Doreen Massey. In the postmodern context of cultural geographies, we encounter the groundbreaking ideas of David Harvey (such as "time-space compression") and Fredric Jameson, who examines "the new spatiality implicit in the postmodern" (418). Therefore, during the last decades, geocritical approaches have taken centre stage in critical studies on an international level. While attempting to map out the heterogeneity of global spaces, at the intersection between literature and socio-political structures, in order to reveal "the role of place in the life of literature, and the role of literature in the production of place" (Luria 67), geocritical explorations have themselves become heterogeneous, transdisciplinary, and come under constant scrutiny. All these different approaches display "the creative interaction between geography and the humanities" (Richardson et al. 3) and showcase surprising outcomes.

Space and place have become "totemic concepts" (Hubbard and Kitchin 2) in the effort to interrogate the relationship between literature, ideological representations and real-and-imagined spaces. Such undertakings aim to set off a "socio-spatial dialectic", revealing "how social forces become manifest in geographies, and how geography is constitutive of social relations" (Dear 3). For the developments in current geocritical studies, human geography and its practices have become relevant, as researchers in the field reconsidered the link between social dimensions and spatial entanglements. Marc 
Augé defined the concept of "non-place" and its functionality in what he calls "supermodernity" (in Non-Places: Introduction to an Anthropology of Supermodernity, 1995), Michel de Certeau offers a relevant distinction between space and place, but also pursues the difference between strategy and tactics especially in a modern urban setting (in The Practice of Everyday Life, 1984), E. C. Relph reveals the underpinnings of notions surrounding place (perceptual, existential, cognitive, abstract etc.) and placelessness (1976). Other contributions that offer insights into the topic are Yi-Fu Tuan's Space and Place: The Perspective of Experience (1977), David Morris' The Sense of Space (2004), Paul Rodaway's Sensuous Geographies: Body, Sense and Place (1994), Sarah Whatmore's Hybrid Geographies (2002), and David Sibley's Geographies of Exclusion (1995). Notable edited volumes dealing with issues raised by human geography are Embodied Geographies: Spaces, Bodies and Rites of Passage (1999), Timespace: Geographies of Temporality (2001), and Mapping the Subject: Geographies of Cultural Transformations (1995). The volume Key Thinkers on Space and Place (2004) delivers a comprehensive overview on the contributions brought to this particular research field. A more recent and noteworthy publication "that explores the meaning of place, and attempts to reconstruct those meanings in ways that produce new knowledge and better-informed scholarly or political practices" (3) is Geohumanities: Art, History, Text at the Edge of Place (2011). This edited collection examines the relationship between geography, spatiality, texts, images and maps through a conceptual frame that integrates geocreativity, geopoetics, geotexts, geoimagery, and geohistory.

Robert T. Tally Jr., Bertrand Westphal, and Franco Moretti are the major researchers on geocriticism that have interrogated the role of spatiality in literary studies. In his book Spatiality (2013), Tally Jr. tackles the relationship between literary geography and cartography, starting from the way both ideas on space and mapping have shifted in cultural history and were reconsidered after the spatial turn, as the latter undermined the dominance of the temporal paradigm in social and philosophical theories. For Tally Jr., "to the writer's literary cartography, we might add the reader's literary geography. The critical reader becomes a kind of geographer who actively interprets the literary map in such a way as to present new, sometimes hitherto unforeseen mappings" (Spatiality 79). The process of "mapping narratives" is 
successfully applied in the collection coordinated by Tally Jr., Literary Cartographies: Spatiality, Representation, and Narrative (2014), as it "surveys a broad expanse of literary historical territories, including romance and realism, modernism and imperialism, and the postmodern play of spaces in the era of globalization", and "explores the ways authors use both strictly mimetic and more fantastic means to figure forth what Edward Soja has called the 'real-and-imagined' spaces of their respective worlds" (4). Another collaborative project led by Tally Jr., Geocritical Explorations: Space, Place, and Mapping in Literary and Cultural Studies (2011), is conceived "as both a companion and a counterpoint to Westphal's Geocriticism, demonstrating the heterogeneity of geocritical practices" (3), while Ecocriticism and Geocriticism: Overlapping Territories in Environmental and Spatial Literary Studies (2016) uncovers the entanglements of geocritical and ecocritical practices with an "emphasis on the lived environment, social and natural spaces, spatiotemporality, ecology, history, and geography" (Tally Jr. and Battista 8), and therefore attempting to map the anthropocene. A review of Tally Jr.'s most recent book, Topophrenia. Place, Narrative and Spatial Imagination (2019), can be found in our current journal issue.

In quantitative analyses and digital humanities, Franco Moretti's methodology takes on an influential role in literary studies across the world. The title of our issue, Space in Literature and Literature in Space, is taken from his Atlas of the European Novel (180o-19oo), a fundamental contribution to the field. The founding father of geocriticism in its current understanding is Bertrand Westphal, who defines the major principles of geocritical practices: transgressivity, multifocalization, geocentered perspectives, and referentiality, in his 2007 book La Géocritique. Réel, Fiction, Espace. For Westphal, "geocriticism will work to map possible worlds, to create plural and paradoxical maps, because it embraces space in its mobile heterogeneity" (73). This "creative interaction" between spatiality anf literature could also be found in Christian Moraru's Reading for the Planet: Toward a Geomethodology (2015), that proposes "a planetary model of cultural production and interpretation" (2).

Another noteworthy contribution to spatial criticism is that of Jonathan Flatley. In Affective Mapping: Melancholia and the Politics of Modernism (2008), Flatley suggests reading literature through the process of affective mapping, which displays a rhizomatic structure borrowing from Fredric Jameson's concept of "cognitive mapping". 
Geocritical approaches to poetry are emphasized in Ian Davidson's Ideas of Space in Contemporary Poetry (2007), Tom Bristow's The Anthropocene Lyric: An Affective Geography of Poetry, Person, Place (2015), and Heather H. Yeung's Spatial Engagement with Poetry (2015). The Routledge Handbook of Literature and Space (2017), featuring contributions from Marc Brosseau, Eric Prieto, Sheila Hones, Barbara Piatti, and others, is a highly recommended reading, as it offers an overview on current methodologies and directions followed in spatial studies.

In Romania, the "spatial turn" is an emergent phenomenon, with attempts in the works of young scholars, usually complemented by quantitative or digital inquiries. There are few theoretical articles that aim to interrogate the application of this developing methodology in literary studies, such as Andrei Terian's Constructing Transnational Identities: The Spatial Turn in Contemporary Literary Historiography (2013). This article explores the ramifications and benefits, but also the risks, losses and the challenges that geocritical practices raise for literary historians. Romanian critics, at least some of whom are worth mentioning in this brief overview, like Cornel Ungureanu, Andreea Răsuceanu, or Corin Braga, have tested, however, conventional geocritical approaches, with more than notable outcomes. The literary critics authored what are probably the most important works to date engaging with Romanian canonical productions from a geocritical point of view. Furthermore, their inquiries also test the very limits, potential, and shortcomings of the geocritical instruments and methods. The works of Cornel Ungureanu, like Literary Geography [Geografie literară] (2002) for instance, are fundamental for the theoretical framework of literary geography developed in Romania and for the many challenging aspects its methodologies display, as they ultimately have to deal with a minor literary culture. Nevertheless, such endeavours constitute a starting point in peripheral studies in Romania ${ }^{1}$. Andreea Răsuceanu's Mircea Eliade's Bucharest [Bucureștiul lui Mircea Eliade] (2013) and The Literary Bucharest: Six possible readings of the City [Bucureștiul literar: Șase lecturi posibile ale orașului] (2016) are probably the most comprehensive geocritical studies on the literary portrayals of Bucharest in works of canonical Romanian fiction, while her latest

\footnotetext{
${ }^{1}$ Another notable contribution to this particular subfield of studies that investigates representations of the peripheral space in the Romanian literature is Georgiana Sârbu's Histories of the Periphery. The Slum in the Romanian novel, from G.M. Zamfirescu to Radu Aldulescu [Istoriile periferiei. Mahalaua in romanul românesc, de la G.M. Zamfirescu la Radu Aldulescu], Cartea Românească, 2009.
} 
project, co-authored with Corina Ciocârlie, Dictionary of Fictional Bucharest [Dicționar de locuri literare bucureștene] (2019), completes her research in a brand new formula. Răsuceanu delivers crucial arguments regarding the relation between space - urban space, architecture - and subjective memory and affectivity, all rooted in Bertrand Westphal's theoretical system. The maps of Bucharest featured in her work are simultaneously sociological, psychological, and aesthetic, often subjecting the mythical and mystical dimensions they expose to a thorough analysis (especially in the case of Mircea Eliade). While her contribution is fundamental for the study of authors' fictional worlds, Răsuceanu's books are also a turning point in the permeation and evolution of geocritical studies in Romania. The author not only provides extremely relevant critical perspectives on this canonical set of literary works, but also a well-structured and dynamic synthesis of the field of study in its global dimension. In fact, the topic of symbolic geographies, the locations of utopian, science fiction and fantasy literature ${ }^{2}$, as well as the ideological dimensions that the notion of space can foster, received quite a fair share of attention in the Romanian context. Corin Braga has not only provided excellent contributions to this field (in his utopian studies published in France), but he has actually worked with expanding the limits of the theoretical framework, both in terms of vision and methodological instruments 3 . The relation between national identity, ideology, and space is another issue that has concerned Romanian authors4.

One of the more recent projects that combines quantitative and digital methods and geocriticism, following mostly the morettian model, is the collective volume Ruralism and Literature in Romania (2020), coordinated by Ștefan Baghiu, Vlad Pojoga, and Maria Sass. The volume provides one of the most important contemporary contributions concerning Romanian rural literature. Testing the limits of such

\footnotetext{
${ }^{2}$ Marius Conkan has had a sustained preoccupation for this subject. His volume, The Portal and the Secondary Worlds. Spatial Typologies in Fantasy Literature [Portalul și lumile secundare. Tipologii ale spațiului în literatura fantasy], Tracus Arte, 2017, as well as his most recent contributions in academic journals and edited volumes, are valuable additions to the domain.

3 Building on Corin Braga's research, another notable contribution is Florin Balotescu's Poetic Space: Revolutions, Developments, Transformations [Spațiul poetic: revoluții, emergențe, mutații], Tracus Arte, 2018. Balotescu's volume aims to redefine the way we perceive the poetic space or the space in poetry. Owing more to poetic studies than geocritical studies, the author succeeds, nonetheless, to deliver an interesting panorama of experimental spaces extrapolated from a diverse corpus of Romanian poetry.

4 Radu Pavel Gheo's volume, Foreign Man in a Foreign Country. Romanian Literature and Identity Boundaries. Herta Müller and Andrei Codrescu [Străin în țară străină: Literatura română și granița identitară în proza Hertei Müller şi a lui Andrei Codrescu], Editura Universității de Vest, 2017 is worth mentioning for the transnational ramifications of such an inquiry.
} 
intersectional methodologies, the authors share new and insightful findings regarding the many clichés that have led to a so-called embargo the rural literature or on representations of rural space in our culture. Using graphs and maps, the contributors of this volume are quite convincing in their claim that rural literature is not a dominant subgenre in the novelistic production (Cosmin Borza), in showing the internal dynamics between rurality and ideology in canonical works (Alex Goldiş, Ştefan Baghiu), or engaging in the non-human or post-human aspects pertaining to literary representations of the rural (Andrei Terian, Mihai Iovănel). In the same fashion and making use of statistical tools, the geography of the $19^{\text {th }}$ century Romanian novel is subjected to a detailed analysis in Stefan Baghiu et al. The Internal Geography of the Romanian Novel in the $19^{\text {th }}$ Century, while, in her recent article, Geocriticism: For an Interpretation of the Romanian Novel about the Revolution of 1989, Teodora Susarenco explores, with notable conclusions, the depiction of space in Romanian novels addressing the events of the 1989 Revolution. Another contribution, relevant for the study of the historical Avant-Garde in eastern and central Europe, is Emanuel Modoc's critical debut, The International of Peripheries. Avant-Garde Networks of East-Central Europe [Internaționala periferiilor. Rețeaua avangardelor din Europa Centrală si de Est] (2020). The volume is an extensive analysis that integrates the Romanian Avant-Garde authors in a broader network, departing from the traditional centre-periphery dynamic that dominated this subfield.

The present issue of our journal is yet another contribution to this complex field of geohumanities. A preliminary interview with Professor Bertrand Westphal inaugurates our contributors' inquiries and provides a stimulating setting for the entire issue. Gathering a series of exceptional articles, making use of a rather diverse pool of methodological instruments, theoretical frameworks, while analysing a mixed literary corpus ranging from the Eastern European to the Latin American space and beyond, our thematic issue aims to engage in the many possibilities provided by geocritical and spatial studies. In her compelling analysis of J. G. Ballard's High Rise, Alina Cojocaru integrates this particular work in a larger network and resorts to the already canonical geocritical works of Bertrand Westphal in her argumentation, as well as to Jungian and Freudian psychoanalysis. Our contributor exposes and investigates the interdependence of human identity and architectural constructions in a dystopian London, showing how 
"urban spaces do not represent mere empty vessels, but repositories of personal and collective memories". The connection between urban architecture and identity is also the leading subject of Maša Uzelac's analysis of Aldous Huxley's and Michel Houellebecq's works. Maša Uzelac's paper proposes a Lefebvrian reading of the novels and focuses on the social functions of space, as depicted in the aforementioned authors' literary works. Symbolic geography is also one of the main interests of Marco Petrelli while investigating the US gothic literature. Using geocritical instruments and theoretical perspectives, such as those provided by Frederic Jameson, Gilles Deleuze and Félix Guattari, the author presents a compelling radiography of the symbolic space of Southern American literary works. Another subject our contributors took interest in was exile, migration, and their cultural echoes, both in the source- and in the targetculture. In this sense, Mihai Țapu presents the functions and the mutations of the LatinAmerican macho figure as they are shaped by migration and exile. Owing to migration studies, as well as gender studies, our colleague delivers an in-depth reading of Junot Diaz's short stories. In her article, Ioana Pavel targets the migration phenomenon from Romania to Italy as it is depicted in the works of Dan Lungu and Liliana Corobca. The author exposes in detail the sociological and psychological effects that this particular phenomenon has upon the characters. The aftermath of exile and the functions of diasporic societies are also subjected to analysis in Nkululeko Sibanda's article, which aims to reveal the phenomenon of disruption and the notions of utopia and dystopia as they are represented in the short stories of Bongani Sibanda.

Working in the field of World Literature studies and using statistical and visual arguments and tools, Ovio Olaru and Snejana Ung's papers offer useful insights into how the notions of national, supranational, and border space are challenged. Ovio Olaru's text provides a radiography of the symptomatic scenery choices in Scandinavian literature and their ideological and political implications, while Snejana Ung delivers a detailed investigation of post-Yugoslavian literature's spatial dimension and its many ideological complexities, while exposing the hegemonic character cultivated by World Literature studies.

Our issue concludes with an assortment of reviews on some of the most recent edited works on spatial studies. We set out to gather a wide range of studies advancing 
original and relevant directions in the field of geocriticism, transnational, and spatial studies, and we gladly confirm that our expectations were most definitely met.

\section{References:}

Augé, Marc. Non-Places: Introduction to an Anthropology of Supermodernity. Verso, 1995.

Baghiu, Ștefan, Vlad Pojoga, and Maria Sass (Eds.). Ruralism and Literature. Peter Lang, 2020.

Baghiu, Ștefan, Vlad Pojoga, Teodora Susarenco, Radu Vancu, and Emanuel Modoc. "The Internal Geography of the Romanian Novel in the $19^{\text {th }}$ Century." Transilvania, no. 10, 2019, pp. 29-43.

Balotescu, Florin. Spațiul poetic: revoluții, emergențe, mutații. Tracus Arte, 2018.

Braga, Corin. Du paradis perdu à l'antiutopie aux XVIe-XVIIIe siècles. Garnier, 2010.

---. Les antiutopies classiques. Garnier, 2012.

---. Morfologia lumilor posibile. Utopie, antiutopie, science-fiction, fantasy. Tracus Arte, 2015.

---. Pour une morphologie du genre utopique. Garnier, 2018.

Bristow, Tom. The Anthropocene Lyric: An Affective Geography of Poetry, Person, Place. Palgrave Macmillan, 2015.

Conkan, Marius. Portalul şi lumile secundare. Tipologii ale spaţiului în literatura fantasy. Tracus Arte, 2017.

---. "Mapping Literature: Geocritical Thinking and Posthumanism." Echinox Journal, no. 34,2018 , pp. 66-76.

Davidson, Ian. Ideas of Space in Contemporary Poetry. Palgrave Macmillan, 2007.

De Certeau, Michel. The Practice of Everyday Life, Berkeley. University of California Press, 1984.

Dear, Michael, Jim Ketchum, Sarah Luria, and Douglas Richardson (Eds.). Geohumanities: Art, History, Text at the Edge of Place. Routledge, 2011.

Flatley, Jonathan. Affective Mapping: Melancholia and the Politics of Modernism. Harvard University Press, 2008.

Gheo, Radu Pavel. Străin în țară străină: Literatura română și granița identitară în proza Hertei Müller și a lui Andrei Codrescu. Editura Universității de Vest, 2017. 
METACRITIC JOURNAL FOR COMPARATIVE STUDIES AND THEORY 6.1

Hubbard, Phil, and Ron Kitchin (Eds.). Key Thinkers on Space and Place. Sage, 2011/2004.

Jameson, Fredric. Postmodernism, or: The Cultural Logic of Late Capitalism. Duke UP, 1991.

Kenworthy Teather, Elizabeth (Ed.), Embodied Geographies: Spaces, Bodies and Rites of Passage. Routledge, 1999.

Lefebvre, Henri. The Production of Space. Blackwell, 1991.

May, Jon, and Nigel Thrift (Eds.). Timespace: Geographies of Temporality. Routledge, 2001.

Modoc, Emanuel. Internaționala periferiilor. Rețeaua avangardelor din Europa Centrală si de Est. Muzeul Literaturii Române, 2020.

Moraru, Christian. Reading for the Planet: Toward a Geomethodology. University of Michigan Press, 2015.

Moretti, Franco. Atlas of the European Novel (1800-190o). Verso, 1998.

Morris, David. The Sense of Space. State University of New York Press, 2004.

Pile, Steve, and Nigel Thrift (Eds.). Mapping the Subject: Geographies of Cultural Transformations. Routledge, 1995.

Răsuceanu, Andreea. Bucureștiul lui Mircea Eliade. Humanitas, 2013.

---. Bucureștiul literar: Şase lecturi posibile ale oraşului. Humanitas, 2016.

---. Dicționar de locuri literare bucureștene. Humanitas, 2019.

Relph, E. C. Place and Placelessness. Pion Limited, 1976.

Rodaway, Paul. Sensuous Geographies: Body, Sense and Place. Routledge, 1994.

Sârbu, Georgiana. Istoriile periferiei. Mahalaua in romanul românesc, de la G.M. Zamfirescu la Radu Aldulescu. Cartea Românească, 2009.

Sibley, David. Geographies of Exclusion. Routledge, 1995.

Soja, Edward W. Thirdspace: Journeys to Los Angeles and Other Real-and-Imagined Places. Blackwell, 1996.

Susarenco, Teodora. "Geocriticism: For an Interpretation of the Romanian Novel About the Revolution of 1989." Transilvania, no. 11-12, 2013, pp. 65-69.

Tally Jr., Robert T. (Ed.). Geocritical Explorations: Space, Place, and Mapping in Literary and Cultural Studies. Palgrave Macmillan, 2011.

---. Spatiality. Routledge, 2013. 
---. Literary Cartographies: Spatiality, Representation, and Narrative. Palgrave Macmillan, 2014.

---. The Routledge Handbook of Literature and Space. Routledge, 2017.

Tally Jr., Robert T., and Christine M. Battista (Eds.). Ecocriticism and Geocriticism: Overlapping Territories in Environmental and Spatial Literary Studies. Palgrave Macmillan, 2016.

Terian, Andrei. "Constructing Transnational Identities: The Spatial Turn in Contemporary Literary Historiography.” Primerjalna književnost, no. 36, 2, 2013, pp. 75-84.

Tuan, Yi-Fu. Space and Place: The Perspective of Experience. University of Minnesota Press, 1977/2001.

Ungureanu, Cornel. Geografie literară, Editura Universităţii de Vest, 2002.

---. Mittleleuropa periferïlor. Brumar, 2018.

Westphal, Bertrand. Geocriticism: Real and Fictional Spaces. Palgrave Macmillan, 2011.

Whatmore, Sarah. Hybrid Geographies. Sage, 2002.

Yeung, Heather H. Spatial Engagement with Poetry. Palgrave Macmillan, 2015. 